Arch. Microbiol. 121, 235-240 (1979)

\title{
Protein Synthesizing Systems from Spores and Vegetative Cells of Bacillus cereus
}

\author{
H. A. Bouthit*, R. A. Kieras**, and R. A. Preston \\ Department of Cell and Molecular Biology, Division of Biological Sciences, University of Michigan, Ann Arbor, Michigan 48109, U.S.A.
}

\begin{abstract}
A system of polyphenylalanine synthesis was optimized for a comparison of the polymerizing activities of ribosomes from spores and vegetative cells of Bacillus cereus T. Ribosomes of both types react similarly, showing a magnesium optimum of about $6 \mathrm{mM}$ and spermidine optima of about $5 \mathrm{mM}$ and $4 \mathrm{mM}$ for vegetative and spore ribosomes, respectively. These lead to optimum mono- to multivalent cation rations of 9 and 10 respectively at $100 \mathrm{mM}$ ammonium ion. A comparison of the response of these ribosomes to suboptimal concentrations of magnesium and spermidine show that they differ qualitatively from each other, suggesting that they possess different structure, macromolecular or ionic components.
\end{abstract}

Key words: Ribosomes - Spores - Bacillus Magnesium - Spermidine - Protein - Synthesis.

Several cell-free amino acid incorporating systems from Bacillus have been developed (Bishop et al., 1969; Deutscher et al., 1963; Kobayashi and Halvorson, 1966) based on the system described by Nirenberg and Leder (1964). While these systems have allowed the posing of questions concerning protein synthesis by vegetative cells of Bacillus, analysis of the constraints on in vivo protein synthesis by endospores has been hampered by the harsh methods required for their breakage, (Douthit and Kieras, 1972) and by the unknown effect(s) of ions or enzymes which are released on their disruption.

* To whom offprint requests should be sent

** Present address: Department of Cellular and Developmental Biology, Biological Sciences West, University of Arizona, Tucson, Arizona 85721, U.S.A.

Abbreviations: DFP $=$ diisopropylfluorophosphate; $\mathrm{HEPES}=\mathrm{N}-2-$ hydroxyethylpiperazine- $\mathrm{N}^{\prime}$-2-ethanesulfonic acid
Unlike previous results from Bacillus, we have demonstrated polysome profiles in extracts of dormant spores broken by means expected to cause neither germination nor extensive enzymic alteration (Douthit and Kieras, 1972; Feinsod and Douthit, 1970). From their presence it can be inferred that messenger ribonucleic acid ( $\mathrm{mRNA}$ ) is present in dormant spores, and that translation becomes inhibited at some time during sporulation. We suggest that previous accounts of degraded, inactive ribosomes in spores (Kobayashi, 1972; Kobayashi and Halvorson, 1968; Kobayashi et al., 1965) can be explained by the sensitivity of these ribosomes to degradative agents present during spore disruption and ribosome extraction. Indeed, we have already shown (Kieras et al., 1978) that some of the inactivity of spore ribosomes can be prevented by the use of protease inhibitors during ribosome isolation. However, even the most stringent protection against protease activity did not permit the isolation of fully active spore ribosomes, and this suggested that factors other than proteolytic cleavage are involved in the low activity of spore ribosomes.

Spores of Bacillus contain calcium in amounts up to $3 \%$ of their dry weight; the chelating agent dipicolinic acid (DPA) can account for up to $12 \%$ of the dry weight (Murrell, 1969). Regardless of the method of spore breakage, ionic compounds such as these, as well as enzymes and other macromolecules, would exist in high concentration during the initial stages of the isolation of ribosomes or supernatant factors from spores. Since calcium is known to exchange with the cations of ribosomes (particularly with spermidine and magnesium), and to cause changes both in polymerizing activity and in the stability of ribosomal subunits (Weiss et al., 1973; Choi and Carr, 1967), part of the inactivity of spore ribosomes cited in the literature could be caused by an 'abnormal' cationic complement established during isolation. This could be manifested in ionic optima for in vitro protein synthesis distinctly 
different from those of ribosomes from vegetative cells.

The present experiments were undertaken to ascertain the extent to which optimum ionic conditions for in vitro protein synthesis by spore and vegetative ribosomes differ.

\section{Materials and Methods \\ Preparation of Cell-Free Extract $\left(S_{100}\right)$}

Cells of Bacillus cereus $\mathrm{T}$ were grown in modified ' $\mathrm{G}$ ' medium (Church et al., 1954). Modifications included raising the concentrations of glucose (to $12 \mathrm{~g} / \mathrm{l}$ ) and $\mathrm{KH}_{2} \mathrm{PO}_{4}$ (to $1.5 \mathrm{~g} / 1$ ), and reducing the ammonium sulfate concentration (to $3 \mathrm{~g} / 1$ ). This formulation more closely approximates the elemental ratios of cells, and allows a larger population of cells to develop without the onset of sporulation. Cells were grown in a Labline Hi-density fermentor, with pure oxygen in the gas phase, to an $\mathrm{A}_{660}$ of about 2.5. At this point, when the cells were just beginning to become granular, they were cooled in an ice bath to $0^{\circ} \mathrm{C}$, harvested by centrifugation, and washed twice with buffer $2[10 \mathrm{mM}$ tris(hydroxymethyl)-aminomethane (Tris), $60 \mathrm{mM} \mathrm{NH}_{4} \mathrm{Cl}, 10 \mathrm{mM} \mathrm{MgCl}, 5 \mathrm{mM}_{2}$-mercaptoethanol, $10 \%$ glycerol, and $5 \mathrm{mM} \mathrm{Mg}$ :ethylenediaminetetraacetic acid 1:1 chelate (MgEDTA) pH 7.5] made $1 \mathrm{M}$ with $\mathrm{KCl}$. Cells were then washed two times more with buffer 2 which was made $0.2 \mathrm{mM}$ in diisopropylfluorophosphate (DFP), but lacking $\mathrm{KCl}$. Washed cells were broken in the French Press, clarified by centrifugation $(20,000$ and $30,000 \times g$ for $15 \mathrm{~min}$ each), after which the ribosomes were harvested at $203,000 \times g(\max )$ for $300 \mathrm{~min}$ at $0^{\circ} \mathrm{C}$. The supernatant $\left(S_{100}\right)$ was dialyzed against two changes of 10 volumes of buffer 2 (containing $0.2 \mathrm{mM} \mathrm{DFP}$ ) for $2 \mathrm{~h}$ each, frozen in $1 \mathrm{ml}$ fractions, and stored at $-70^{\circ} \mathrm{C}$. Thawed samples were discarded if not used.

\section{Preparation of Vegetative Ribosomes}

The ribosomal pellet from above was suspended in buffer $1(60 \mathrm{mM}$ Tris, $10 \mathrm{mM}$ magnesium acetate, $100 \mathrm{mM} \mathrm{NH}_{4} \mathrm{Cl}, 10 \%$ glycerol, $4 \mathrm{mM}$ 2-mercaptoethanol, $5 \mathrm{mM}$ MgEDTA, 0.2 mM DFP, pH 7.5), and layered over a $14 \mathrm{ml}$ cushion of $50 \% \mathrm{glycerol}$ in buffer 1 in a $60 \mathrm{Ti}$ polycarbonate tube. Ribosomes were pelleted through this cushion at $250,700 \times g(\max )$ for $2 \mathrm{~h}$, dissolved in the same buffer and, once again, pelleted under the same conditions. They were finally dissolved in the same buffer at a final concentration of $30-80 \mathrm{~A}_{260} / \mathrm{ml}$ and stored at $-70^{\circ} \mathrm{C}$.

\section{Preparation of Spore Ribosomes}

Spores were grown and disrupted as previously described (Douthit and Kieras, 1972). The broken spores $(0.75 \mathrm{~g})$ were hydrated in $10 \mathrm{mi}$ of buffer 2 containing $0.2 \mathrm{mM}$ DFP, treated with $1 \mu \mathrm{g} / \mathrm{ml} \mathrm{de}$ oxyribonuclease (IUB 3.1.4.5) for $10 \mathrm{~min}$ on ice, and clarified by centrifugation at $30,600 \times g$ for $30 \mathrm{~min}$ at $4^{\circ} \mathrm{C}$. The clear, strawcolored supernatant was centrifuged through $50 \%$ glycerol in buffer 1 , like the procedure for the vegetative ribosomes. These ribosomes were suspended in buffer 1 , clarified by centrifugation at $20,000 \times g$ (max) for $15 \mathrm{~min}$, and brought to a pellet by centrifugation at 313,934 $\times g(\max )$ for $60 \mathrm{~min}$. Finally, these were suspended in a buffer 1 at $30-80 \mathrm{~A}_{260} / \mathrm{ml}$ and stored at $-70^{\circ} \mathrm{C}$.

\section{In vitro Assay of Protein Synthesis}

In general these reactions were carried out in groups of 4 or 5 . A stock reaction mixture was prepared and stored frozen in $0.5 \mathrm{ml}$ portions for these assays. It contained: $3 \mathrm{mg} / \mathrm{ml}$ transfer ribonucleic acid (Grand Island Biological Co.), $1 \mathrm{mg} / \mathrm{ml}$ polyuridylic acid (Sigma type II), $250 \mu \mathrm{M}$ each of 21 amino acids (excluding phenylalanine), $1 \mathrm{mM}$ guanosine triphosphate (Sigma), $10 \mathrm{mM}$ adenosine triphosphate (Sigma), and $20 \mathrm{mM}$ phosphoenolpyruvic acid (Sigma). In the order presented, the following were added to small test tubes on ice (final concentrations in parentheses): N-2-hydroxyethylpiperazine- $\mathrm{N}^{\prime}-2$ ethanesulfonic acid (HEPES) buffer, pH 7.8 unless otherwise indicated $(50 \mathrm{mM})$, spermidine (variable), $\mathrm{NH}_{4} \mathrm{Cl}$ (variable), magnesium acetate (variable), 2-mercaptoethanol $(4 \mathrm{mM})$, glycerol $(10 \%), \mathrm{H}_{2} \mathrm{O}$ (to a final volume of $0.5 \mathrm{ml}$ ), ${ }^{14} \mathrm{C}$-phenylalanine $(0.76 \mu \mathrm{Ci} / \mathrm{ml}, 1,630 \mathrm{pmol} / \mathrm{ml})$, stock reaction mix $(600 \mu \mathrm{g} / \mathrm{ml} \mathrm{tRNA}$, $200 \mu \mathrm{g} / \mathrm{ml}$ polyuridylic acid, $50 \mu \mathrm{M}$ each of 21 amino acids, $200 \mu \mathrm{M}$ guanosine triphosphate, $2 \mathrm{mM}$ adenosine triphosphate, $4 \mathrm{mM}$ phosphoenolpyruvic acid), pyruvate kinase (IUB 2.7.1.40) $(40 \mu \mathrm{g} / \mathrm{ml}$ ), and $\mathrm{S}_{100}$ (variable). Tubes were mixed, preincubated for $5 \mathrm{~min}$ at $37^{\circ} \mathrm{C}$ in a water bath, and the reaction started by the addition of ribosomes. Samples $(50 \mu 1)$ were taken at $2.5,5.0,7.5$, and 10 min and quickly pipetted onto numbered rectangles of Whatman $3 \mathrm{MM}$ filter paper. As soon as the entire sample had soaked into the paper it was dropped into $10 \%$ trichloroacetic acid (TCA) where it was stored until all samples had been taken. The TCA was then brought to and held at $90^{\circ} \mathrm{C}$ for $5 \mathrm{~min}$. After cooling to $70^{\circ} \mathrm{C}$, the papers were washed twice ( 5 min each with agitation) in about $300 \mathrm{ml} 10 \% \mathrm{TCA}$, and then successively with a mixture of ether and n-propanol $(2: 1)$, and ether. They were dried under a heat lamp, submerged under $10 \mathrm{ml} \mathrm{of} 0.4 \%$ 2,5-bis-2(5-tert-butylbenzoxazolyl)-thiophene (BBOT) in toulene, and counted in a Beckman scintillation counter. Typical non-specific adsorption of radioisotope to paper by this procedure was about $100 \mathrm{ct} / \mathrm{min}$ above background (ca. $40 \mathrm{ct} / \mathrm{min}$ ). Initial rates were calculated by a linear regression through uncorrected data points (ct/min with time), and converted into pmol phenylalanine incorporated per min per nmole ribosomes with the appropriate constants.

\section{Miscellaneous Procedures}

Protein was assayed by the procedure of Lowry et al. (1951), with appropriate corrections made for the contribution by HEPES buffer. Bovine serum albumin served as standard. Ribosomal RNA was estimated spectrophotometrically by assuming $50 \mu \mathrm{g}$ RNA equals 1.0 $\mathrm{A}_{260}$. Ribosome concentration was calculated using a molecular weight of $2.8 \times 10^{6}$.

\section{Results}

Assay Conditions for Polymerizing Activity by Vegetative Ribosomes

To compare the polymerizing activities of vegetative and spore ribosomes under varying ionic conditions, we felt it was necesarry to assay initial rates of phenylalanine incorporation into an acid-insoluble precipitate in ribosome-limited reactions. In preliminary experiments we established the concentration of soluble components $\left(S_{100}\right)$ required to produce high rates of polymerization of phenylalanine with vegetative ribosomes. Subsequent ionic optimization assays were performed under ribosome-limited conditions by adjusting the quantity of ribosomes to ensure that rates of polymerization never exceeded $50 \%$ of the maximum 

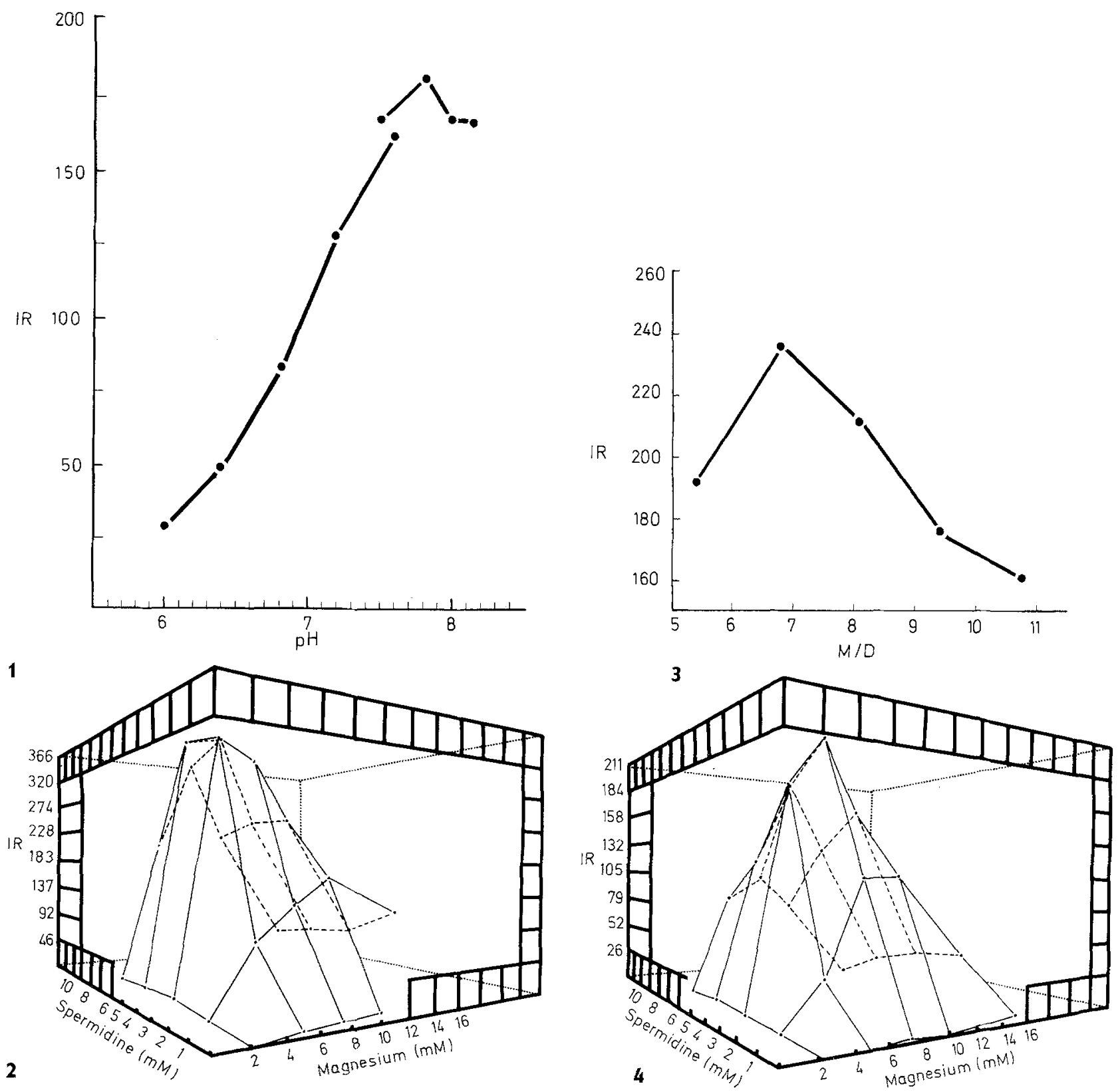

Fig. 1. Response of initial rate (IR) of protein synthesis as a function of $\mathrm{pH}$. Two experiments are shown as two unconnected lines

Fig. 2. Response of initial rate (IR) of protein synthesis to changes in the concentrations of magnesium and spermidine. Vegetative ribosomes Fig. 3. Response of initial rate (IR) of protein synthesis to changes in the ratio of mono- to multivalent cations (M/D). Vegetative ribosones Fig. 4. Response of initial rate (IR) of protein synthesis to changes in the concentrations of magnesium and spermidine. Spore ribosomes

possible with the chosen quantity of $S_{100}(785 \mu \mathrm{g}$ protein $/ 0.5 \mathrm{ml}$ reaction). Also, since phenylalanine incorporation is proportional to time for at least $12 \mathrm{~min}$ in our reactions, rates were calculated over the first $10 \mathrm{~min}$.

Figure 1 displays the response of vegetative ribosomes to changes in $\mathrm{pH}$. Data shown in this figure were taken from two experiments, separated in time by about one week, and indicate the range of data scatter that can be expected from one time to the next. The $\mathrm{pH}$ values indicated in this figure were measured at $37^{\circ} \mathrm{C}$ in reaction mixtures prepared exactly like those used for measuring incorporation except that they lacked ribosomes. They indicate a rather sharp $\mathrm{pH}$ optimum of about 7.8 , and a rapid fall in rate with drop in $\mathrm{pH}$. Values of $\mathrm{pH}$ lower than about 7.5 were associated with precipitation of some component(s) of the system. Although we did not study the effect of different buffers 
extensively, we found that at any tested $\mathrm{pH}$, the initial rate of incorporation was lower in reactions buffered by Tris than in those buffered by HEPES (data not shown).

Optimum concentrations of magnesium and spermidine are strongly interdependent. This is shown for vegetative ribosomes in Fig. 2. In these reactions, the ammonium concentration was held constant (at $100 \mathrm{mM}$ ), while concentrations of the other two cations were varied independently. Corresponding initial rates were plotted as a function of both multivalent cations in three dimensions, a display which allows estimation of multiple optima in a system such as this with multiple interdependent variables. Thus, at $100 \mathrm{mM}$ ammonium, vegetative ribosomes function maximally at about $6 \mathrm{mM}$ magnesoum and $5 \mathrm{mM}$ spermidine.

These conditions correspond to a mono- to multivalent cation ratio (M/D) of 9.1. (Note that since HEPES in uncharged, or negatively charged at neutral $\mathrm{pH}$, it does not enter into calculations of $\mathrm{M} / \mathrm{D}$ as Tris would.) However, the optimum M/D ratio depends on the levels of all cations involved, not just magnesium and spermidine. For example, if these two ions are held constant (at $5 \mathrm{mM}$ and $2.5 \mathrm{mM}$ respectively) while the concentration of ammonium is varied, the optimum M/D ratio is found to be 6.8 (Fig. 3).

\section{The Response of Spore Ribosomes}

When in vitro rates of polymerization are measured with ribosomes from dormant spores, the response is similar to that of vegetative ribosomes. Figure 4 shows the variation in initial polymerization rate in response to changes in the concentrations of magnesium and spermidine. From this figure, it can be estimated that optimum conditions for spore ribosomes are obtained at about $6 \mathrm{mM}$ magnesium and $4 \mathrm{mM}$ spermidine, corresponding to an M/D ratio of about 10 .

Using the data of Figs. 2 and 4, a point to point comparison of the response of vegetative and spore ribosomes upon changes in the concentrations of magnesium and spermidine was made. These data are presented in Fig. 5 as the percent of vegetative polymerizing activity shown by spore ribosomes under the same conditions. A maximum occurs in this surface, at $7.5 \mathrm{mM}$ magnesium and $2 \mathrm{mM}$ spermidine. This corresponds approximately to the magnesium optimum for both ribosome types, and to a spermidine concentration considerably below the optimum level for both types of ribosomes.

\section{Discussion}

We have described a system of in vitro protein synthesis that we feel is adequate for a comparison of vegetative and spore ribosomes from Bacillus cereus $\mathrm{T}$. The initial rates quoted here are difficult to compare with values in the literature because of the diversity of units and different times of measurement that have been quoted. Nevertheless, we have assembled data (Table 1) from three different species of Bacillus with which such a comparison can be attempted. Its validity clearly rests on the appropriateness of the assumptions involved. Although the calculated rates from the literature may be slightly high or low, we believe them to be accurate enough for comparative purposes. This table shows that, with the single exception of salt-washed ribosomes from vegetative cells of $B$. subtilis, the in vitro system described in this communication is superior to all others described for Bacillus. It also indicates something of the constancy with which the phenylalanine incorporating activity of spore ribosomes has been found to be less than that of vegetative ribosomes, as well as the magnitude of such differences.

In most respects, the system described is similar to other systems from Bacillus. Although the broad $\mathrm{pH}$ optimum for $B$. cereus ribosomes mentioned by Kobayashi and Halvorson (1966) was not supported by data in this paper, their reaction mixtures were buffered with Tris, whereas HEPES buffer was used in the present study. Tris buffer has very little buffering capacity against added acids at $\mathrm{pH} 7.5$; acidic nature of some components of the in vitro reaction mixture and the precipitation problems described here may help explain the differences in our results in this respect. Our magnesium optimum $(6 \mathrm{mM})$ is somewhat lower than values reported for other Bacillus systems (LegaultDemare and Chambliss, 1974; Kobayashi and Halvorson, 1966), but considering the complex interactions of cations in protein synthesis, these differences are perhaps not significant. The optimum spermidine concentration for spore ribosomes $(4 \mathrm{mM})$ may be slightly less than for vegetative ribosomes $(5 \mathrm{mM})$. However, the values are very close to each other, and the difference may be within experimental error.

The polymerizing activity of spore ribosomes is never quite as high as that of vegetative ribosomes (see Table 1 for spore activity in percent). This may mean that, as presently prepared and assayed, spore preparations contain a higher percent of damaged particles, an interpretation that is consistent with the effects of protection from protease activity (see Kieras et al., 1978). More effective protection from such enzymic degradation might decrease the difference between the two types of ribosomes even more.

Two facts argue against proteolytic damage as the only explanation for the polymerizing activity difference, however. Firstly, a large proportion of spore ribosomes are isolated as polysomes (Douthit and Kieras, 1972). Before these could participate in poly- 
Table 1. Polymerizing activities of ribosomes from spores and vegetative cells of Bacillus

\begin{tabular}{|c|c|c|c|c|c|c|c|c|}
\hline \multirow[t]{3}{*}{ Organism } & \multirow[t]{3}{*}{ Expt } & \multicolumn{3}{|c|}{ Activity quoted } & \multicolumn{2}{|c|}{$\begin{array}{l}\text { Calculated activity } \\
\text { pmol Phe/min }\end{array}$} & \multirow{3}{*}{$\begin{array}{l}\text { Spore } \\
\text { activity } \\
\%\end{array}$} & \multirow[t]{3}{*}{ Reference } \\
\hline & & \multirow[t]{2}{*}{ units $^{a}$} & \multirow[t]{2}{*}{ veg } & \multirow[t]{2}{*}{ spore } & nmol & ribosomes & & \\
\hline & & & & & Veg & Spore & & \\
\hline \multirow[t]{4}{*}{ B. megaterium } & 1 & A & 360 & 353 & 171 & 168 & 98 & \multirow{3}{*}{$\begin{array}{l}\text { Deutscher et al. } \\
\text { (1968) }\end{array}$} \\
\hline & 2 & & 208 & 216 & 99 & 102 & 103 & \\
\hline & 3 & & 278 & 279 & 132 & 132 & 100 & \\
\hline & 1 & $\mathrm{~B}$ & 724 & 123 & 267 & 45 & 17 & $\begin{array}{l}\text { Idriss and } \\
\text { Halvorson (1969) }\end{array}$ \\
\hline \multirow[t]{3}{*}{ B. subtilis } & 1 & C & 317 & 182 & 38 & 19 & 50 & $\begin{array}{l}\text { Bishop et al. } \\
(1969)\end{array}$ \\
\hline & 1 & $\mathrm{D}$ & 166 & - & 221 & - & - & Legault-Demare \\
\hline & $2^{c}$ & & 900 & - & 1200 & - & - & $\begin{array}{l}\text { and Chambliss } \\
\text { (1976) }\end{array}$ \\
\hline \multirow[t]{8}{*}{ B. cereus } & 1 & $\mathrm{E}$ & 949 & 16 & 16 & 0.3 & 2 & $\begin{array}{l}\text { Kobayashi et al. } \\
(1965)\end{array}$ \\
\hline & 1 & $E$ & 10,800 & - & 187 & - & - & $\begin{array}{l}\text { Kobayashi and } \\
\text { Halvorson }(1966)\end{array}$ \\
\hline & 1 & $\mathrm{D}$ & 665 & 96 & 241 & 35 & 15 & $\begin{array}{l}\text { Idriss and } \\
\text { Halvorson (1969) }\end{array}$ \\
\hline & 1 & $\mathrm{~F}$ & $10-15$ & - & $172-259$ & 一 & - & Kohayashi (1972) \\
\hline & 1 & $F$ & 8.4 & 0.4 & 145 & 6.9 & 5 & Kobayashi (1973) \\
\hline & $2^{c}$ & & 14.2 & 0.6 & 245 & 10.4 & 4.2 & Kieras et al. (1978) \\
\hline & 1 & - & - & - & 410 & $\begin{array}{l}\text { Unfractionated } \\
150\end{array}$ & 36 & \\
\hline & & & & & & Polysomes 220 & 53 & \\
\hline
\end{tabular}

a Activities as quoted in the several papers: A. $\mu \mu \mathrm{mol}$ Phe incorporated in $30 \mathrm{~min}$ at $37^{\circ} \mathrm{C}$ by $70 \mu \mathrm{g}$ ribosomal protein; B. pmol Phe incorporated in $30 \mathrm{~min}$ at $37^{\circ} \mathrm{C}$ by $95 \mu \mathrm{g}$ ribosomal protein; C. pmol Phe incorporated in $10 \mathrm{~min}$ at $37^{\circ} \mathrm{C}$ by one mg ribosomal protein; D. pmol Phe incorporated in $30 \mathrm{~min}$ at $37^{\circ} \mathrm{C}$ by $70 \mu \mathrm{g}$ ribosomes. E. $\mu \mu \mathrm{mol}$ Phe incorporated in $60 \mathrm{~min}$ at $36^{\circ} \mathrm{C}$ by one mg ribosomal protein; F. nmol Phe incorporated in $60 \mathrm{~min}$ at $36^{\circ} \mathrm{C}$ by one $\mathrm{mg}$ ribosomal protein

6 Assumptions involved in rate calculations: a. RNA : protein ratio of $1.7: 1 ; \mathrm{b}$. $50 \mu \mathrm{g}$ RNA per $\mathrm{A}_{260}$; c. ribosomal molecular weight $2.7 \times 10^{6} ; \mathrm{d}$. linear incorporation rates to the times quoted in the papers. This approximation seems valid for most of the papers quoted here. based on data provided in the papers. It would lead to an underestimate of the data of Legault-Demare and Chambliss

c Ribosomes used in these experiments were washed in buffers of high ionic strength

phenylalanine synthesis, they would have to be released from association with mRNA, tRNA, and nascent polypeptide, and then become associated with poly-U. Thus a non-linear response with time would be predicted, which would cause an underestimate of rate, if initial rate is calculated from zero time. A suggestion of such an activity lag appears in some preparations from spores and is currently under investigation. Secondly, Fig. 5 demonstrates a qualitatively different response of spore and vegetative ribosomes to perturbations in their ionic environment. If the two preparations had simply had a different percent of active, qualitatively identical ribosomes, then the ratio of their activities should have reflected that difference. For example, if the vegetative preparation had $80 \%$ active ribosomes, and the spore ppeparation $40 \%$ active ribosomes, and the active ribosomes were essentially identical, then the spore preparation should always have $50 \%$ the activity of the vegetative one; Fig. 5 would have shown a flat surface at the $50 \%$ level.

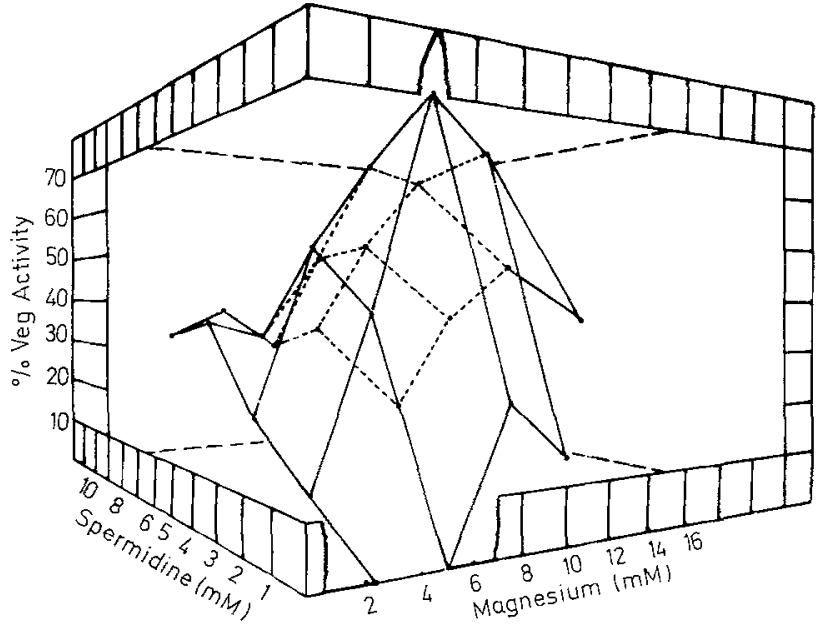

Fig. 5. Comparison of the responses of spore and vegetative ribosomes to ionic perturbations. The percent of vegetative polymerizing activity at each magnesium and spermidine concentration obtained by spore ribosomes is plotted as a function of the concentrations of magnesium and spermidine 
The curved surface of Fig. 5, however, with a striking maximum at $7.5 \mathrm{mM}$ magnesium and $2 \mathrm{mM}$ spermidine indicates a differential response to changes in the concentrations of these ions. We think it likely that at least part of this differential response is due to exchange of magnesium for calcium occurring in spore ribosomes either during sporulation or during ribosome isolation. Calcium-loaded ribosomes of Escherichia coli have been reported to have properties strongly reminiscent of some of those of ribosomes from Bacillus spores (Kieras et al., 1978; Weiss et al., 1973).

Acknowledgements. This work was supported by grant 1R01GM20296 from the National Institute of General Medical Sciences and by a grant (FRG Douthit) from the University of Michigan.

\section{References}

Bishop, H. L., Migita, L. K., Doi, R. H. : Peptide synthesis by extracts trom Bacillits subtilis spores. J. Bacteriol. 99, $771-778$ (1969)

Choi, Y.S., Carr, C. W.: Ion-binding studies of ribonucleic acid and Escherichia coli ribosomes. J. Mol. Biol, 25, 331-345 (1967)

Church, B. D., Halvorson, H., Halvorson, H. O : Studies on spore germination: its independence from alanine racemase activity. J. Bacteriol. 68, 393-399 (1954)

Deutscher, M. P., Chambon, P., Kornberg, A.: Biochemical studies of bacterial sporulation and germination, XI. Proteinsynthesizing systems from vegetative cells and spores of Bacillus megaterium. J. Biol. Chem. 243, 5117-5125 (1968)

Douthit, H. A., Kieras, R. A. : Polyribosomes in spores of Bacillus. In: Spores V (H. O. Halvorson, R. Hanson, L. L. Campbell, eds.), pp. 264-268. Washington D.C.: American Society for Microbiology 1972

Feinsod, F. M., Douthit, H. A.: Ribosomes from spores of Bacillus cereus T. Science 168, 991 (1970)
Idriss, J. M., Halvorson, H. O.: The nature of spores of Bacillus cereus $\mathrm{T}$ and Bacillus megaterium. Arch. Biochem. Biophys. 133, $442-453$ (1969)

Kieras, R. A., Preston, R. A., Douthit, H. A.: Isolation of stable ribosomes from spores of Bacillus cereus. J. Bacteriol. 136, 209 $218(1978)$

Kobayashi, Y., Steinberg, W., Higa, A., Halvorson, H. O., Levinthal, C.: Sequential synthesis of macromolecules during outgrowth of bacterial spores. In: Spores III (L. L. Campbell, H. O. Halvorson, eds.), pp. 200-212. Ann Arbor, Michigan: American Society for Microbiology 1965

Kobayashi, Y., Halvorson, H. O. : Incorporation of amino acids into protein in a cell-free system from Bacillus cereus. Biochim. Biophys. Acta 119, 160-170 (1966)

Kobayashi, Y., Halvorson, H. O.: Evidence for a defective protein synthesizing system in dormant spores of Bacillus cereus. Arch. Biochem. Biophys. 123, 622-632 (1968)

Kobayashi, Y.: Activation of dormant spore ribosomes during germination. II. Existence of defective ribosomal subunits in dormant spore ribosomes. In: Spores V (H. O. Halvorson, R. Hanson, L. L. Campbell, eds.), pp. 269-276. Washington D.C.: American Society of Microbiology 1972

Kobayashi, Y.: Characterization of ribosomes from dormant spores of Bacillus cereus. Agric. Biol. Chem. 37, 1929-1934 (1973)

Legault-Demare, L., Chambliss, G. H.: Natural messenger ribonucleic acid-directed cell-free protein-synthesizing system of Bacillus subtilis. J. Bacteriol. 120, 1300-1307 (1974)

Lowry, O. H., Rosebrough, N. J,, Farr, A. L., Randall, R. J. : Protein measurement with the folin phenol reagent. J. Biol. Chem. 193, $265-275(1951)$

Murrell, W. G.: Chemical composition of spores and spore structures. In: The bacterial spore (G. W. Gould, Hurst, eds.), pp. 215-273. New York: Academic Press 1969

Nirenberg, M. W., Leder, P. : RNA codewords and protein synthesis. The effect of trinucleotides upon the binding of sRNA to ribosomes. Science 145, 1399-1407 (1964)

Weiss, R. L., Kines, B. W., Morris, D. R.: Cations and ribosome structure. III. Effects on the $30 \mathrm{~S}$ and $50 \mathrm{~S}$ subunits of replacing bound $\mathrm{Mg}^{2+}$ by inorganic cations. Biochem. 12, 450-456 (1973)

Received October 18, 1978 